\title{
Warning Credit Risk for Vietnamese Commercial Banks - Case Study: Corporate Customer
}

\author{
Assoc. Prof, PhD. Nguyen Van Huan; Dr. Nguyen Thi Hang; Mr. Do Nang Thang \\ Faculty of Economic Information System - Information and Communication \\ Technology Thai Nguyen University
}

\begin{abstract}
Stemming from the urgency of the actual situation, commercial banks need an effective credit risk management tool to limit risks. The authors went to survey, study and propose a set of factors affecting the ability of debt repayment of individual customers and conducting surveys. The topic uses data sets including 240 observation samples. Using the SPSS software to clean data and run the model based on Maddala's Binary logistics regression published in 1984 to find out the impact of each individual element of customers affecting their ability to repay such debts. Come on. The authors also specify the order of influence of each factor determining the ability to repay individual customers, thereby helping bank managers have a better visual view to make decisions for borrowing accurately, limiting risks.
\end{abstract}

Keywords: warning model, credit risk, logistics model

\section{Introduction}

Credit risk management is a very important activity it has received interest of every banks, currently there are many research projects on the world related to this research problem, of which typical is the Merton Model (1974) has an enlightening role in field of credit risk management, this model defines debt repayment ability of the company based on the calculation company's asset value at some time and compared with the company's debt with the assumption that the company only has a debt and has to pay at a single time, this is the limitation of the Merton model because the debt structure of the companies is very complex now. To overcome the limitations of the grading model depends a lot on the qualitative data, Altman (1977) has produced the Z score model. Model Z score calculates the customer's repayment capability base on historical data of factors affect to customer's repayment ability. The Z-score model used a multi-factor difference analysis method to quantify the probability of default of borrowers overcoming the disadvantages of the qualitative model, thus contributing positively to controlling Credit risks at commercial banks. However, this model is highly dependent on how to classify risky and risk-free borrowers. On the other hand, the model requires a fully updated information system of all customers. This requirement is very difficult to 
implement in an inadequate market economy. The CreditMetrics model, introduced by JP Morgan in 1997, is a model commonly used in practice. This model can be viewed as derived from the Merton model, however there is a fundamental difference between the CreditMetrics model and Merton. That is, the bankruptcy threshold in CreditMetrics model is determined from credit ratings rather than debt. Therefore, this model allows to determine both the probability of default and the probability of a credit decline. However, due to the requirements of the stability of external ranking systems, CreditMetrics model often does not reflect the financial situation of a company properly. When applying the CrediMetrics model to the catalog, we also need to assume a normal distribution.

In Vietnam, there are many research projects mentioning the construction of a credit risk warning model that has been published but mainly applying the model of the world to warn risk in the environment of Viet Nam such as the research of Mr. Le Van Tuan in 2008 "Exploring the interesting of R software in quantifying credit risks" in the study, the author has researched and applied KMV model to risk warning or the second research of Mr. Le Van Tuan "Merton model application in teaching credit risk and bond valuation for financial students" this research has clarified the Merton model and application in credit risk warning at commercial banks in Vietnam. however, the above models only mention financial factors without mentioning non-financial factors. Stemming from the urgency of the actual situation, authors went to survey, study and propose a set of factors affecting the ability of debt repayment of individual customers and conducting surveys. The topic uses data sets including 240 observation samples. Using the SPSS software to clean data and run the model based on Maddala's Binary logistics regression published in 1984 to find out the impact of each individual element of customers affecting their ability to repay such debts. Come on. The authors also specify the order of influence of each factor determining the ability to repay individual customers, thereby helping bank managers have a better visual view to make decisions for borrowing accurately, limiting risks.

\section{Materials and Methods}

\subsection{Materials}

\section{Introduce of logistics model}

\section{General form of the logistics model}

Binary logistic regression model [Maddala (1983)] is a quantitative model in which the dependent variable is a dummy variable, only two values are 0 or 1 . This model is widely used in general economic analysis and particular credit risks. More specifically, this model can help the Bank determine the ability of customers to have credit risk 
(dependent variable) on the basis of using factors that affect customers (independent variables).

Data structure of Logistic model

Table 1. Convention of dependent and independent variable

\begin{tabular}{|l|l|l|}
\hline Variable & Sign & Species \\
\hline Dependent & $\mathrm{Y}$ & Binary \\
\hline Independent & $\mathrm{X}$ & Continuous or discrete \\
\hline
\end{tabular}

$\mathrm{Y}$ is a binary variable that can only accept either value 0 or 1

$\mathrm{Y}=0$ : Customers are unable to pay debts

$\mathrm{Y}=1$ : Customers have the ability to pay debts

Probability to $\mathrm{Y}=0: \mathrm{p}$

Probability to $\mathrm{Y}=1: 1-\mathrm{p}$

There are 2 types of logit regression:

Single logit regression:

$$
\begin{aligned}
& p=\frac{1}{1+e^{-\left(\beta_{0}+\beta_{1} X\right)}}=\frac{e^{\beta_{0}+\beta_{1} X}}{1+e^{\beta_{0}+\beta_{1} X}} \\
& 1-p=\frac{1}{1+e^{\beta_{0}+\beta_{1} X}}
\end{aligned}
$$

Odds of events occur:

$$
\begin{aligned}
& \text { Odds }=\frac{p}{1-p}=\frac{1+e^{\beta_{0}+\beta_{1} X}}{1+e^{-\left(\beta_{0}+\beta_{1} X\right)}}=e^{\beta_{0}+\beta_{1} X} \\
& \operatorname{Ln}(\text { Odds })=\operatorname{Ln}\left(\frac{p}{1-p}\right)=\ln \left(e^{\beta_{0}+\beta_{1} X}\right)=\beta_{0}+\beta_{1} X \\
& \text { Or: } \operatorname{Logit}=\operatorname{Ln}(\text { Odds })=\beta_{0}+\beta_{1} X
\end{aligned}
$$

Consider the change of Odds when independent variables (explanatory variables) $\mathrm{X}$ increase by 1 unit (from $\mathrm{X}$ to $\mathrm{X}+1$ ). We have:

$$
\begin{aligned}
& \text { Khi } X=X_{1} \longrightarrow \operatorname{Ln}\left(\text { Odd }^{1}\right)=\beta_{0}+\beta_{1} X_{1} \\
& \text { Khi } X=X_{1}+1 \rightarrow \operatorname{Ln}\left(\text { Odd }^{2}\right)=\beta_{0}+\beta_{1}\left(X_{1}+1\right)=\operatorname{Ln}\left(\text { Odd }^{1}\right)+\beta_{1} \\
& \rightarrow \beta_{1}=\operatorname{Ln}\left(\text { Odd }^{2}\right)-\operatorname{Ln}\left(\text { Odd }^{1}\right)=\operatorname{Ln}\left(\frac{\text { Odd }^{2}}{\text { Odd } s^{1}}\right)=\operatorname{LnOR} \\
& \rightarrow O R=e^{\beta_{1}}
\end{aligned}
$$


Meaning: Increase 1 unit of the independent variable is $\operatorname{Odds}^{2}$ equal to $e^{\beta_{1}}$ time compared with $\boldsymbol{O d d s}^{1}$. If $e^{\beta_{1}}>1$ (or $\left.\beta 1>0\right)$, Odds ${ }^{2}$ increases $e^{\beta_{1}}$ time $\operatorname{Odds}^{1}\left(\operatorname{Odds}^{2}=\right.$

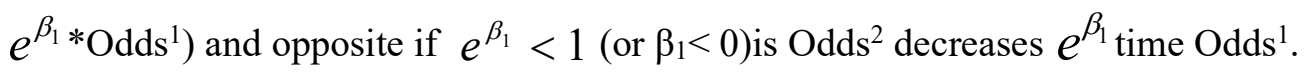

As in linear regression, we estimate the parameters $\beta 0$ and $\beta 1$ from the sample, then use appropriate statistical tests to consider their statistical significance.

The hypothesis hypothesis is:

$\mathrm{H}_{0}: \beta_{1}=0 \rightarrow$ independent variable does not affect the probability of event occurrence;

$\mathrm{H}_{1}: \beta_{1} \neq 0 \rightarrow$ independent variables affect the probability of an event occurring.

In case of regression logit regression then:

Logit $=\operatorname{Ln}($ Odds $)=\beta_{0}+\beta_{1} X_{1}+\ldots+\beta_{k} X_{k}$

\subsection{Methods}

2.2.1. Building research model

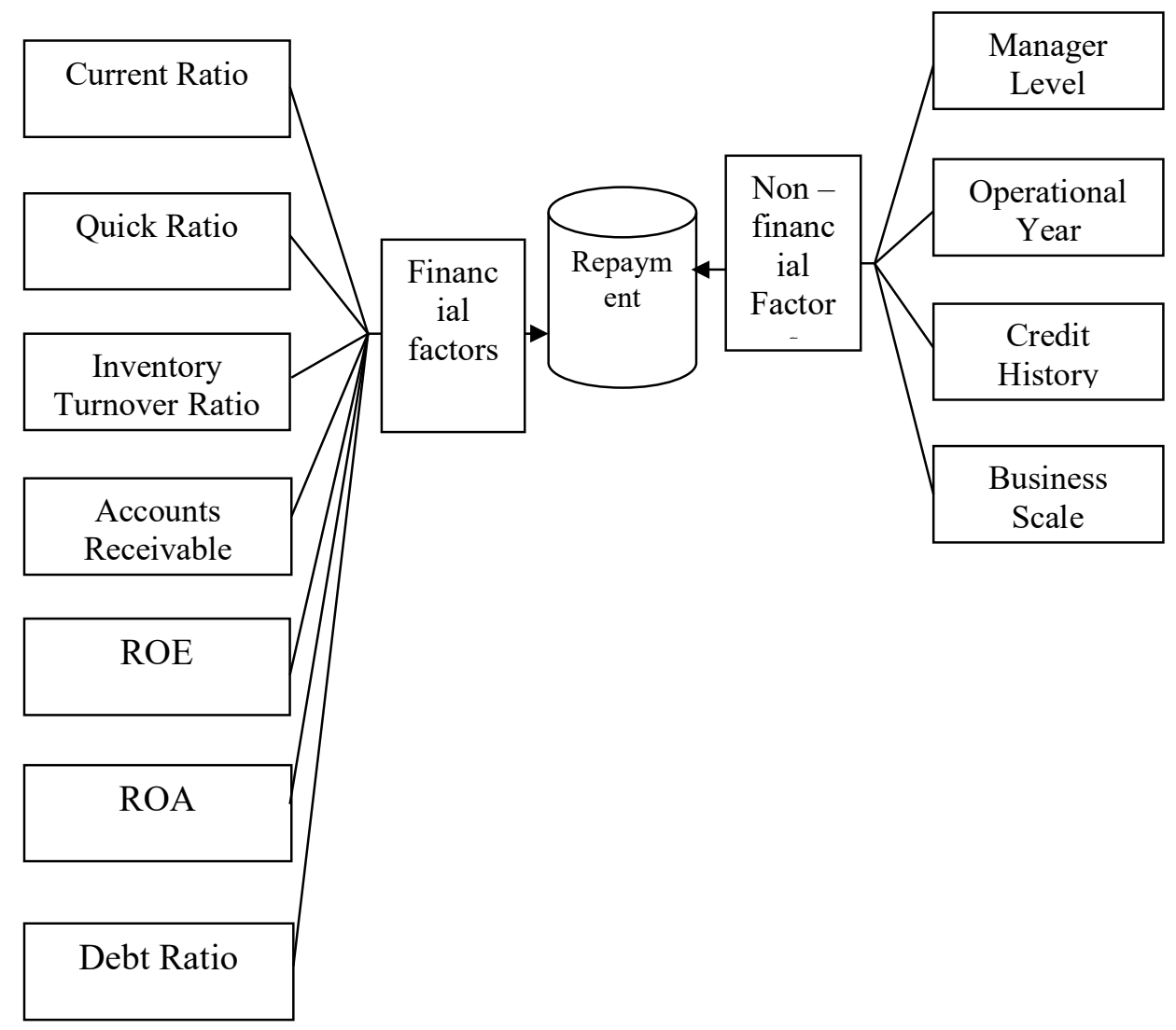

Figure 1. Model for the effect of independent variables affecting debt repayment capacity 


\subsubsection{Select variables in the model}

The topic uses set of data including of 240 observations sample. Using SPSS software to clean data and use Binary logistics regression model to find out the impact of each individual element of the customer affects their ability to pay debts.

\section{Dependent variable}

Y: Repayment

$\mathrm{Y}=1:$ If the customer is able to repay

$\mathrm{Y}=0$ : If the customer is unable to repay

\section{Independent variables}

Table 2. Information of independent variables

\begin{tabular}{|c|c|c|c|c|}
\hline $\begin{array}{c}\text { Ordinal } \\
\text { Numbers }\end{array}$ & Variables & Scale & Hypothesis & Symbol \\
\hline 1 & Current Ratio & $\frac{\text { Current assets }}{\text { Short }- \text { term liabilities }}$ & + & $\mathrm{X}_{1}$ \\
\hline 2 & Quick ratio & $\frac{\text { Current assets }- \text { Inventory }}{\text { Short }- \text { term liabilities }}$ & + & $\mathrm{X}_{2}$ \\
\hline 3 & $\begin{array}{l}\text { Inventory Turnover } \\
\text { Ratio }\end{array}$ & $\frac{\text { Cost of goods sold }}{\text { Average of Inventory }}$ & + & $\mathrm{X}_{3}$ \\
\hline 4 & $\begin{array}{l}\text { Accounts Receivable } \\
\text { Turnover }\end{array}$ & $\frac{\text { Revenue }}{\text { Average of Accounts Receivable }}$ & + & $\mathrm{X}_{4}$ \\
\hline 5 & Debt Ratio & $\frac{\text { Total liability }}{\text { Total Assets }}$ & - & $\mathrm{X}_{5}$ \\
\hline 6 & Bank loans & tens of billion dong & - & $\mathrm{X}_{6}$ \\
\hline 7 & ROA & $\frac{\text { Profit after taxes }}{\text { Total Assets }}$ & + & $\mathrm{X}_{7}$ \\
\hline 8 & $\mathrm{ROE}$ & $\frac{\text { Profit after taxes }}{\text { Owners' equity }}$ & + & $\mathrm{X}_{8}$ \\
\hline \multirow{2}{*}{9} & \multirow{2}{*}{ Manager Level } & 0: Under university & - & \multirow{2}{*}{$\mathrm{X}_{9}$} \\
\hline & & 1: After university & + & \\
\hline \multirow{2}{*}{10} & \multirow{2}{*}{ Credit history } & $0:$ repayment in full and on time & + & \multirow{2}{*}{$\mathrm{X}_{10}$} \\
\hline & & 1: Repayment not on time & - & \\
\hline
\end{tabular}




\begin{tabular}{|c|c|c|c|c|}
\hline \multirow{2}{*}{11} & \multirow{2}{*}{ Operational Year } & 0 : Under three year & - & \multirow{2}{*}{$\mathrm{X}_{11}$} \\
\hline & & 1: After three year & + & \\
\hline \multirow{2}{*}{12} & \multirow{2}{*}{ Business scale } & $\begin{array}{c}\text { 0: Small and medium } \\
\text { enterprises }\end{array}$ & - & \multirow{2}{*}{$\mathrm{X}_{12}$} \\
\hline & & 1: Big enterprises & + & \\
\hline
\end{tabular}

\section{Result}

3.1. Logistic model

Table 3. Variables in the Equation

\begin{tabular}{|l|l|l|l|l|l|l|}
\hline & B & S.E & Wald & df & Sig. & Exp(B) \\
\hline Current Ratio & 4.293 & 1.613 & 7.084 & 1 & .008 & 73.161 \\
\hline Quick ratio & 3.139 & 1.489 & 4.441 & 1 & .035 & 23.076 \\
\hline Inventory Turnover Ratio & 2.370 & 1.051 & 5.090 & 1 & .024 & 10.702 \\
\hline Accounts Receivable Turnover & .930 & .455 & 4.178 & 1 & .041 & 2.534 \\
\hline Debt Ratio & -2.349 & 1.134 & 4.292 & 1 & .038 & .095 \\
\hline Bank loans & -.262 & .125 & 4.427 & 1 & .035 & .769 \\
\hline ROE & .115 & .057 & 4.097 & 1 & .043 & 1.122 \\
\hline ROA & .340 & .159 & 4.582 & 1 & .032 & 1.405 \\
\hline Manager Level & 3.342 & 1.441 & 5.378 & 1 & .020 & 28.269 \\
\hline Operational Year & 2.997 & 1.433 & 4.372 & 1 & .037 & 20.032 \\
\hline Credit History & -19.141 & 6.709 & 8.139 & 1 & .004 & .000 \\
\hline Business scale & 2.365 & 1.183 & 4.001 & 1 & .045 & 10.648 \\
\hline Constant & 1.348 & 3.968 & 1 & .046 & .068 \\
\hline
\end{tabular}

Source: Data analysis results from SPSS 
The general logistic regression equation has the form:

$$
\begin{aligned}
& \text { Ln(odds) }=B_{0}+B_{1} X_{1}+B_{2} X_{2}+B_{3} X_{3}+B_{4} X_{4}+B_{5} X_{5}+B_{6} X_{6}+B_{7} X_{7}+ \\
& B_{8} X_{8}+B_{9} X_{9}+B_{10} X_{10}+B_{11} X_{11}+B_{12} X_{12}
\end{aligned}
$$

From the logistic regression analysis table, we can write the logistic equation in the economic direction as follows:

$$
\begin{gathered}
\mathrm{Ln}(\text { odds })=-19.141+4.293 * \mathrm{X}_{1}+3.139 * \mathrm{X}_{2}+2.370 * \mathrm{X}_{3}+0.930 * \mathrm{X}_{4}-2.349 * \mathrm{X}_{5}- \\
0.262 * \mathrm{X}_{6}+0.115 * \mathrm{X}_{7}+0.340 * \mathrm{X}_{8}+3.342 * \mathrm{X}_{9}+2.997 * \mathrm{X}_{10}-2.685 * \mathrm{X}_{11}+2.365 * \mathrm{X}_{12}
\end{gathered}
$$

\begin{tabular}{|c|c|c|c|c|c|c|}
\hline \multirow[t]{2}{*}{$\begin{array}{c}\text { Ordinal } \\
\text { Numbers }\end{array}$} & \multirow[t]{2}{*}{ Variables } & \multirow[t]{2}{*}{ B } & \multirow{2}{*}{ EXP(B) } & \multirow{2}{*}{\begin{tabular}{|c} 
Initial \\
probability \\
$\boldsymbol{P}_{\mathbf{0}}=\mathbf{1 0} \%$ \\
$\boldsymbol{P}_{\mathbf{1}}$
\end{tabular}} & \multirow{2}{*}{$\begin{array}{c}\text { Level of } \\
\text { increase } \\
\text { or } \\
\text { decreas } \\
\text { e\% }\end{array}$} & \multirow[t]{2}{*}{$\begin{array}{l}\text { Level of } \\
\text { influence }\end{array}$} \\
\hline & & & & & & \\
\hline 1 & Current Ratio & 4.293 & 73.161 & 89 & 79 & 1 \\
\hline 2 & Quick ratio & 3.139 & 23.076 & 72 & 62 & 3 \\
\hline 3 & $\begin{array}{l}\text { Inventory Turnover } \\
\text { Ratio }\end{array}$ & 2.370 & 10.702 & 54 & 44 & 5 \\
\hline 4 & $\begin{array}{l}\text { Accounts Receivable } \\
\text { Turnover }\end{array}$ & 0.930 & 2.534 & 22 & 12 & 6 \\
\hline 5 & Debt Ratio & -2.349 & 0.095 & 1 & -9 & 7 \\
\hline 6 & Bank loans & -0.262 & 0.769 & 8 & -2 & 9 \\
\hline 7 & ROA & 0.115 & 1.122 & 11 & 1 & 10 \\
\hline 8 & ROE & 0.340 & 1.405 & 14 & 4 & 8 \\
\hline 9 & Manager Level & 3.342 & 28.269 & 76 & 66 & 2 \\
\hline 10 & Credit history & 2.997 & 20.032 & 69 & 59 & 4 \\
\hline 11 & Operational Year & -2.685 & 0.068 & 9 & -1 & 10 \\
\hline 12 & Business scale & 2.365 & 10.648 & 54 & 44 & 5 \\
\hline
\end{tabular}

3.2. Determining influence level of independent variables on debt repayment (Dependent)

Table 4. The influence level of independent variables on debt repayment

Source: Data analysis results from SPSS 


\subsection{Inspection system of the model}

\subsubsection{Wald lnspection}

Performing Binary Logistics regression analysis with SPSS (Sig <0.05), we get the following results:

Table 5. Variables in the Equation

\begin{tabular}{|l|l|l|l|l|l|l|}
\hline & B & S.E & Wald & df & Sig. & Exp(B) \\
\hline Current Ratio & 4.293 & 1.613 & 7.084 & 1 & .008 & 73.161 \\
\hline Quick ratio & 3.139 & 1.489 & 4.441 & 1 & .035 & 23.076 \\
\hline Inventory Turnover Ratio & 2.370 & 1.051 & 5.090 & 1 & .024 & 10.702 \\
\hline Accounts Receivable Turnover & .930 & .455 & 4.178 & 1 & .041 & 2.534 \\
\hline Debt Ratio & -2.349 & 1.134 & 4.292 & 1 & .038 & .095 \\
\hline Bank loans & -.262 & .125 & 4.427 & 1 & .035 & .769 \\
\hline ROE & .115 & .057 & 4.097 & 1 & .043 & 1.122 \\
\hline ROA & .340 & .159 & 4.582 & 1 & .032 & 1.405 \\
\hline Manager Level & 3.342 & 1.441 & 5.378 & 1 & .020 & 28.269 \\
\hline Operational Year & 2.997 & 1.433 & 4.372 & 1 & .037 & 20.032 \\
\hline Credit History & -2.685 & 1.348 & 3.968 & 1 & .046 & .068 \\
\hline Business scale & 2.365 & 1.183 & 4.001 & 1 & .045 & 10.648 \\
\hline Constant & -19.141 & 6.709 & 8.139 & 1 & .004 & .000 \\
\hline
\end{tabular}

Source: Data analysis results from SPSS

From the above Logistics regression analysis results, we find that the value of the sig significance level of the independent variables is all $<0.05$, so the independent variables in the Binary logistics regression model have a correlation with the dependent variable is Repay. The statistical significance level of the above regression coefficients has a reliability of over $95 \%$, the sign of the regression coefficients is consistent with the initial hypothesis

3.3.2. Testing the relevance of the model (Omnibus test) 
Table 6. Omnibus Tests of Model Coefficients

\begin{tabular}{cccc}
\hline & Chi-square & df & Sig. \\
\hline Step & 158.912 & 12 & .000 \\
\hline Block & 158.912 & 12 & .000 \\
\hline Model & 158.912 & 12 & .000 \\
\hline
\end{tabular}

Source: Data analysis results from SPSS

Based on the results of testing the suitability of the model, we have sig $<0.05$ so the general model shows the correlation between the dependent variable and the independent variables in the model are statistically significant with confidence intervals above $99 \%$

\subsubsection{Testing the explanation level of the model}

Table 7. Model Summary

\begin{tabular}{c|c|c|c|}
\hline Step & $\begin{array}{c}\mathbf{- 2} \text { Log } \\
\text { likelihood }\end{array}$ & $\begin{array}{c}\text { Cox \& Snell R } \\
\text { Square }\end{array}$ & $\begin{array}{c}\text { Nagelkerke R } \\
\text { Square }\end{array}$ \\
\hline 1 & $33.508^{\mathrm{a}}$ & .531 & .885 \\
\hline
\end{tabular}

Source: Data analysis results from SPSS

a. Estimation terminated at iteration number 10 because parameter estimates changed by less than .001 .

Explanatory coefficient of model: R2 Nagelkerke $=0.885$. This means that $88.5 \%$ of the variation of the dependent variable is explained by 12 independent variables in the model, the rest is due to other factors.

\subsubsection{Testing the level of predicting the accuracy of the model}

Table 8. Classification Table ${ }^{a}$

\begin{tabular}{|c|c|c|c|c|}
\hline & \multirow{3}{*}{ Observed } & \multicolumn{3}{|c|}{ Predicted } \\
\hline & & \multicolumn{2}{|c|}{ Repay } & \multirow{2}{*}{$\begin{array}{c}\text { Percentage } \\
\text { Correct }\end{array}$} \\
\hline & & $\begin{array}{c}\text { unable to pay } \\
\text { debts }\end{array}$ & $\begin{array}{c}\text { able to pay } \\
\text { debts }\end{array}$ & \\
\hline \multirow{2}{*}{ Repay } & Unable to pay debts & 31 & 5 & 86.1 \\
\hline & Able to pay debts & 3 & 171 & 98.3 \\
\hline \multicolumn{2}{|c|}{ Overall Percentage } & & & 96.2 \\
\hline
\end{tabular}

Source: Data analysis results from SPSS

a. The cut value is .500 
- In 36 responses, individuals who are unable to pay debts, the forecasting model is exactly 31 , so the correct rate is $86.1 \%$.

- In 174, the individuals who can pay the debt, the forecasting model is exactly 171 , so the correct rate is $98.3 \%$.

The correct forecast rate of the entire model is $96.2 \%$

\section{Discussion}

Table 9. Variables in the Equation

\begin{tabular}{|l|l|l|l|l|l|l|}
\hline & \multicolumn{1}{|c|}{ B } & \multicolumn{1}{|c|}{ S.E } & Wald & df & Sig. & Exp(B) \\
\hline Current Ratio & 4.293 & 1.613 & 7.084 & 1 & .008 & 73.161 \\
\hline Quick ratio & 3.139 & 1.489 & 4.441 & 1 & .035 & 23.076 \\
\hline Inventory Turnover Ratio & 2.370 & 1.051 & 5.090 & 1 & .024 & 10.702 \\
\hline Accounts Receivable Turnover & .930 & .455 & 4.178 & 1 & .041 & 2.534 \\
\hline Debt Ratio & -2.349 & 1.134 & 4.292 & 1 & .038 & .095 \\
\hline Bank Loans & -.262 & .125 & 4.427 & 1 & .035 & .769 \\
\hline ROE & .115 & .057 & 4.097 & 1 & .043 & 1.122 \\
\hline ROA & .340 & .159 & 4.582 & 1 & .032 & 1.405 \\
\hline Manager Level & 3.342 & 1.441 & 5.378 & 1 & .020 & 28.269 \\
\hline Operational Year & 2.997 & 1.433 & 4.372 & 1 & .037 & 20.032 \\
\hline Credit History & -2.685 & 1.348 & 3.968 & 1 & .046 & .068 \\
\hline Business scale & 2.365 & 1.183 & 4.001 & 1 & .045 & 10.648 \\
\hline Constant & -19.141 & 6.709 & 8.139 & 1 & .004 & .000 \\
\hline
\end{tabular}

Source: Data analysis results from SPSS

\subsection{Current Ratio}

$$
\begin{aligned}
& \mathrm{B}_{1}=4.293, \mathrm{P}_{0}=10 \%, e^{B_{1}}=e^{4.293}=73.161 \\
& \mathrm{P}_{1}=\frac{P_{0} \times e^{B_{1}}}{1-P_{0}\left(1-e^{B_{1}}\right)}=\frac{0.1 \times 73.161}{1-0.1(1-73.161)}=\frac{7.3161}{8.2161}=0.89
\end{aligned}
$$

If the probability of initially repayment is $10 \%$, when other factors unchanged, if the short-term payment index of the enterprise increases by 1 unit, the probability of paying the debt of that enterprise is $89 \%$ (increase up to $79 \%$ from the initial probability of $10 \%$ )

\subsection{Quick ratio}

$$
\begin{aligned}
& \mathrm{B}_{2}=3.139, \mathrm{P}_{0}=10 \%, e^{B_{2}}=e^{3.139}=23.076 \\
& \mathrm{P}_{1}=\frac{P_{0} \times e^{B_{2}}}{1-P_{0}\left(1-e^{B_{2}}\right)}=\frac{0.1 \times 23.076}{1-0.1(1-23.076)}=\frac{2.3076}{3.2076}=0.72
\end{aligned}
$$


If the initially probability of repayment is $10 \%$, when other remain factors unchanged, if the quick ratio of the enterprise increases by 1 unit, the probability of repaying the enterprise's debt is $72 \%$ (up to $62 \%$ of initial probability is $10 \%$ )

\subsection{Inventory Turnover Ratio}

$$
\begin{aligned}
& \mathrm{B}_{3}=2.370, \mathrm{P}_{0}=10 \%, e^{B_{3}}=e^{2.370}=10.702 \\
& \mathrm{P}_{1}=\frac{P_{0} \times e^{B_{3}}}{1-P_{0}\left(1-e^{B_{3}}\right)}=\frac{0.1 \times 10.702}{1-0.1(1-10.702)}=\frac{1.0702}{1.9702}=0.54
\end{aligned}
$$

If the initial probability of repayment is $10 \%$, when other remain factors unchanged, if the Inventory Turnover Index increases by 1 unit, the probability of repayment debt is $54 \%$ (up to $44 \%$ of initial probability is $10 \%$ )

\subsection{Accounts Receivable Turnover}

$$
\begin{aligned}
& \mathrm{B}_{4}=0.930, \mathrm{P}_{0}=10 \%, e^{B_{4}}=e^{0.930}=2.534 \\
& \mathrm{P}_{1}=\frac{P_{0} \times e^{B_{4}}}{1-P_{0}\left(1-e^{B_{4}}\right)}=\frac{0.1 \times 2.534}{1-0.1(1-2.534)}=\frac{0.2534}{1.1534}=0.22
\end{aligned}
$$

If the initial probability of repayment is $10 \%$, when other remain factors unchanged, if the Receivable Turnover Index increases by 1 , the probability of repayment debt is $22 \%$ (up $12 \%$ compared to the initial probability of $10 \%$ )

\subsection{Debt Ratio}

$$
\begin{aligned}
& \mathrm{B}_{5}=-2.349, \mathrm{P}_{0}=10 \%, e^{B_{5}}=e^{-2.349}=0.095 \\
& \mathrm{P}_{1}=\frac{P_{0} \times e^{B_{5}}}{1-P_{0}\left(1-e^{B_{5}}\right)}=\frac{0.1 \times 0.095}{1-0.1(1-0.095)}=\frac{0.0095}{0.9095}=0.01
\end{aligned}
$$

If the initial probability of debt repayment is $10 \%$, when other remain factors unchanged, if the debt ratio of the enterprise increases by 1 , the individual's probability of repayment debt is $1 \%$ (reduction $9 \%$ compared to the initial probability $10 \%$ )

\subsection{Bank Loans}

$$
\begin{aligned}
& \mathrm{B}_{6}=-0.262, \mathrm{P}_{0}=10 \%, e^{B_{6}}=e^{0.262}=0.769 \\
& \mathrm{P}_{1}=\frac{P_{0} \times e^{B_{6}}}{1-P_{0}\left(1-e^{B_{6}}\right)}=\frac{0.1 \times 0.769}{1-0.1(1-0.769)}=\frac{0.0769}{0.9769}=0.08
\end{aligned}
$$

If the initial probability of repayment is $10 \%$, when other remain factors unchanged, if the business borrows more than 10 billion VND, the probability of repayment debt is $8 \%$ (lower than $2 \%$ compared to the initial probability $10 \%$ ).

\section{7. $R O E$}

$$
\begin{aligned}
& \mathrm{B}_{7}=0.115, \mathrm{P}_{0}=10 \%, e^{B_{7}}=e^{0.115}=1.122 \\
& \mathrm{P}_{1}=\frac{P_{0} \times e^{B_{7}}}{1-P_{0}\left(1-e^{B_{7}}\right)}=\frac{0.1 \times 1.122}{1-0.1(1-1.122)}=\frac{0.1122}{1.0122}=0.11
\end{aligned}
$$


If the initial probability of repayment is $10 \%$, when other remain factors unchanged, if the ROE of the business increases by 1 , the probability of repayment debt of that business is $11 \%$ (up $1 \%$ compared to initial probability is $10 \%$ ).

\section{8. $R O A$}

$$
\begin{aligned}
& \mathrm{B}_{8}=0.340, \mathrm{P}_{0}=10 \%, e^{B_{8}}=e^{0.340}=1.405 \\
& \mathrm{P}_{1}=\frac{P_{0} \times e^{B_{8}}}{1-P_{0}\left(1-e^{B_{8}}\right)}=\frac{0.1 \times 1.405}{1-0.1(1-1.405)}=\frac{0.1405}{1.0405}=0.14
\end{aligned}
$$

If the initial probability of repayment is $10 \%$, when other remain factors unchanged, if the ROA of the business increases by 1 , the probability of repayment debt of that business is $14 \%$ (up $4 \%$ compared with initial probability is $10 \%$ ).

\subsection{Manager Level}

$$
\begin{aligned}
& \mathrm{B}_{9}=3.342, \mathrm{P}_{0}=10 \%, e^{B_{9}}=e^{3.342}=28.269 \\
& \mathrm{P}_{1}=\frac{P_{0} \times e^{B_{9}}}{1-P_{0}\left(1-e^{B_{9}}\right)}=\frac{0.1 \times 28.269}{1-0.1(1-28.269)}=\frac{2.8269}{3.7269}=0.76
\end{aligned}
$$

If the probability of repayment is initially $10 \%$, when other remain factors unchanged, if the manager level of business increases by 1 level, the probability of repaying the debt of that enterprise is $76 \%$ (up $66 \%$ compared with initial probability is $10 \%$ )

\subsection{Operational Year}

$$
\begin{aligned}
& \mathrm{B}_{10}=2.997, \mathrm{P}_{0}=10 \%, e^{B_{10}}=e^{2.997}=20.032 \\
& \mathrm{P}_{1}=\frac{P_{0} \times e^{B_{10}}}{1-P_{0}\left(1-e^{B_{10}}\right)}=\frac{0.1 \times 20.032}{1-0.1(1-20.032)}=\frac{2.0032}{2.9032}=0.69
\end{aligned}
$$

If the initial probability of repayment is $10 \%$, when other remain factors unchanged, if the number of founded years of enterprise increases by 1 year, the probability of repaying the debt of that enterprise is $69 \%$ (up 59\% compared with initial probability is $10 \%$ )

\subsection{Credit history}

$$
\begin{aligned}
& \mathrm{B}_{11}=-2.685, \mathrm{P}_{0}=10 \%, e^{B_{11}}=e^{-2.685}=0.068 \\
& \mathrm{P}_{1}=\frac{P_{0} \times e^{B_{11}}}{1-P_{0}\left(1-e^{B_{11}}\right)}=\frac{0.1 \times 0.068}{1-0.1(1-0.068)}=\frac{0.0068}{2.9032}=0.09
\end{aligned}
$$

If the initial probability of repayment is $10 \%$, when other remain factors unchanged, if the business has a bad credit history, the probability of repaying the debt of enterprise is $9 \%$ ( Reduction 1\% compared with initial probability is $10 \%$ ).

\subsection{Business scale}

$$
\begin{aligned}
& \mathrm{B}_{12}=2.365, \mathrm{P}_{0}=10 \%, e^{B_{12}}=e^{2.365}=10.648 \\
& \mathrm{P}_{1}=\frac{P_{0} \times e^{B_{12}}}{1-P_{0}\left(1-e^{B_{12}}\right)}=\frac{0.1 \times 10.648}{1-0.1(1-10.648)}=\frac{1.0648}{1.9648}=0.54
\end{aligned}
$$


If the initial probability of repayment is $10 \%$, when other remain factors unchanged, if the enterprise has a larger Scale, the probability of repayment of that debt is $54 \%$ (Increase $44 \%$ compared with initial probability is $10 \%$ ).

\section{Conclusions}

Credit risks bring huge consequences for banks. However, facing it is inevitable for every bank, especially in the context of fierce competition nowadays.

Logistic model can support bank managers have an additional tool to analyze and identify businesses are in danger of losing their ability to repay, while the model indicates factors that strongly affect risk Credit for managers to have appropriate focus policies

However, the Logistic model is only effective when the analytical data is standard actual data.

\section{REFERENCES}

[1]. Hoang Trong, Chu Nguyen Mong Ngoc (2008), Analyze research data with SPSS, Hồng Đức Publication.

[2]. Donald J. Bowersox, David J. Closs (2001), Logistical Management: The Integrated Supply Chain Process, Michigan State University, United States

[3]. J. Scott Long \& Jeremy Freese (2001), Regression models for categorical dependent variables using Stata, A Stata Press Publication

[4]. Maddala, GS (1983), "Limited dependent and qualitative variables ineconometrics", Cambridge University Press

[5]. Thomas Goldsby, Robert Martichenko, Robert O. Martichenko (2005), Lean Six SIGMA Logistics: Strategic Development to Operational Success, United States.

[6]. Yosef Sheffi (2012), Logistics Clusters: Delivering Value and Driving Growth, Massachusetts Institute of Technology, United States. 